\title{
POTENTIAL OF USING IMIDAZOLINE IN RECYCLED ASPHALT PAVEMENT
}

\author{
ROBERT JURCZAK, PAWEŁ MIECZKOWSKI, \\ BARTOSZ BUDZIŃSKI ${ }^{*}$ \\ Dept of Roads and Bridges, Faculty of Civil Engineering, \\ West Pomeranian University of Technology, Szczecin, Poland
}

Received 29 November 2018; accepted 2 July 2019

\begin{abstract}
The environmental considerations need to be taken into account in any road resurfacing and upgrading project, for example, by reusing asphalt rubble for production of new pavement courses. Mixtures containing larger amounts of recycled asphalt pavement are improved by adding rejuvenator additives. The tests performed on the recycled asphalt mixtures containing lard imidazoline confirm the suitability of this agent for paving applications. Lard imidazoline was found to improve the stiffness modulus, fatigue performance and resistance to the action of water and freezing temperatures. The parameters obtained at the optimum content of additive complied with the criteria defined for virgin asphalt concrete and other mixtures of that kind.
\end{abstract}

Keywords: fatigue performance, lard imidazoline, recycled asphalt pavement (RAP), stiffness modulus, rut resistance.

* Corresponding author. E-mail: bbudzinski@zt.edu.pl

Robert JURCZAK (ORCID ID 0000-0003-3149-74971)

Paweł MIECZKOWSKI (ORCID ID 0000-0003-2128-53271)

Bartosz BUDZIŃSKI (ORCID ID 0000-0001-6716-44541) 


\section{Introduction}

The asphalt layers of road pavements deteriorate over time. In most cases, this deterioration is related to the change of the properties of the bitumen due to causes, including exposure to environmental factors (ageing, fatigue) and wheel loading (fatigue). The bitumen becomes harder and more brittle, its stiffness increases and the stress relaxation capability decreases as the time goes by.

The chemical reactions between oxygen, bitumen content and ultraviolet thermal radiation are the main causes of deterioration (Feng, Yu, Zhang, Kuang, \& Xue, 2013; Kandhal \& Chakraborty, 1996; Kuang, Yu, Feng, Li, Chen, Guan, \& Zhang, 2014; Lu \& Isacsson, 2002; Paliukaitè, Vaitkus, \& Zofka, 2015; Wu, Pang, Mo, Qiu, Zhu, \& Xiao, 2008). Oxidation occurs primarily during the asphalt mixture production, specifically in the process of mixing aggregate with a binder. The thinness of the film of bitumen coating the grains of mineral aggregate saturated with salts of heavy metals, large amounts of oxygen delivered during mixing and high temperature during the process are the factors responsible for the composition and structure of bitumens (colloidal system). The most prominent changes concern naphthalene aromatics that become converted to resins, and the resins are, in turn, converted to asphaltenes (Liu, Chaffin, Davison, Glover, \& Bullin, 1998; Piłat \& Radziszewski, 2004; Yut \& Zofka, 2014). Thus to recover the binder structure it is necessary to supply oil fractions (abundant in saturated and unsaturated fatty acids) and naphthalene aromatic fractions. The additive does not only improve the properties of bitumen but also, subject to correctly specified ratio, keep the penetration index $P I$ in the range from -1 to +1 to obtain solgel rheological behaviour.

Asphalt rubble (processed to obtain recycled asphalt pavement (RAP) material) was scarcely used in the production of hot-mix asphalt mixtures (HMA). This is inconsistent with the provisions of the Polish law on waste management and disposal of 27 April 2001 (Dz.U. 2001, Issue No. 62, Item No. 628) requiring that "a party undertaking actions that generate or potentially generate waste have to plan, design and perform these actions in a way preventing generation of waste or reducing their amount and take effort to mitigate the environmental impacts during production and use of the produced goods and after their end of life". Even though the Polish code of practice for asphalt mixtures production Polish standard WT-2:2014 Nawierzchnie asfaltowe na drogach krajowych allows using of reclaimed asphalt, the amount that is about to be added is limited to the maximum of $20 \%$ for cold recycling process (i.e. in the plant without "black drum") that prevails 
in most batch plants. Although allowed by the code, the Employers often Potential of Using preclude the use of RAP in mixtures.

Addition of RAP is supposed to be accompanied with adjustment of the process (to avoid any significant deterioration of the bitumen properties) and addition of an appropriate rejuvenator, generally based on naphthalene aromatics (Čygas, Mučinis, Sivilevičius, \& Abukauskas, 2011). A good option is to use double drum continuous asphalt plants in which RAP is fed to the outer drum (thus avoiding direct exposure to the burner flame). One of the available rejuvenators is imidazolines.

\section{The influence of lard imidazoline on the properties of bitumen - experimental research results}

\subsection{Imidazoline - a study of the material}

Imidazolines that are abundant in oil fractions (naphthalene aromatics) are successfully used for rejuvenating aged bitumen contained in reclaimed asphalt material (Bajpai \& Tyagi, 2008; Gawel, Czechowski, \& Kosno, 2016; James \& Steward, 1991). They are classified as heterocyclic organic compounds with surface tension reducing properties (most of them are classified as cationic surfactants). They are obtained by partial hydrogenation of imidazole (Figure 1). Imidazoline has three isomers (resulting from one double bond present in the structure and its location): 2-imidazoline, 3-imidazoline and 4-imidazoline. Additionally, positions 1-, 2- and 3- are occupied by the following substituents: fatty acid, aminoethyl, long alkyl chain or a methyl group. The most widely used of these three isomers, as far as chemistry is concerned, is 2-imidazoline.

Imidazolines with the double bond in position 2 (of 4,5-dihydro- $1 \mathrm{H}$ imidazole) have different tautomeric forms (Figure 2) (James \& Steward, 1991):

- two - in the case of hydrogen or hydrocarbon type substituent,
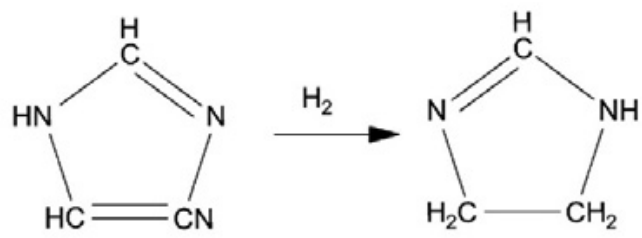

Figure 1. Structure of imidazole, imidazoline molecule 


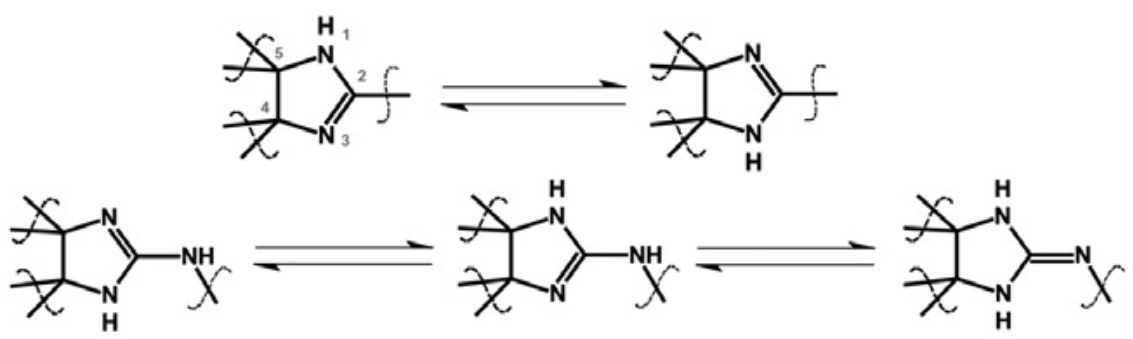

Figure 2. Tautometry of imidazoline and 2-2-iminoimidazoline rings (Bajpai \& Tyagi, 2008)

- three - in the case of substituent containing $-\mathrm{SH},-\mathrm{OH},-\mathrm{NH} 4$ group linked to the ring or substitution with HNR amine group.

The group of cationic surfactants is represented by (James \& Steward, 1991):

- hydroxyethyl imidazoline - is a substance based on fatty acid and aminoethyl ethanolamine (in the ratio of 1:1) that promotes adhesion, dissolves well in water and fats and is used primarily for production of paints, coatings and lubricants;

- aminoethyl imidazoline - is a product of the reaction of fatty acids and diethylenetriamine (in the ratio of 1:1), is used as a dispersant and corrosion inhibitor and is also used as a dewatering agent and emulsifier - primarily in chemical, papermaking and metalworking industries;

- amidoethyl imidazoline - is a product of the reaction of fatty acids and diethylenetriamine (in the ratio of 1:1) and it is used for the production of textile softeners, stable acid detergents and agricultural flocculants.

This research concerns lard imidazoline. It combines the effects of a surfactant, emulsifier, corrosion inhibitor and adhesion promoter. It consists of up to $90 \%$ of imidazolines Type 1 and Type 2 (Figure 3), up

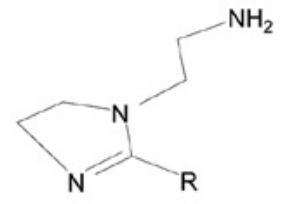

a) Type 1

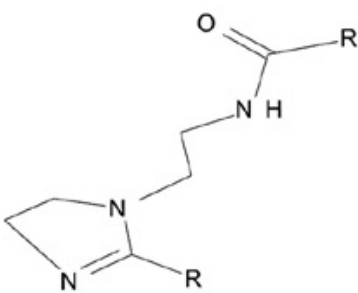

b) Type 2

Figure 3. The structural formula of imidazoline (Bajpai \& Tyagi, 2008) 
O-C $\mathrm{NH}-\left(\mathrm{CH}_{2}\right)_{2}-\mathrm{NH}-\left(\mathrm{CH}_{2}\right)_{2}-\mathrm{NH}_{2}$

a) Type 1<smiles>[R]C1=NCCN1CCN</smiles>

b) Type 2

Figure 4. Formation of imidazolines dehydration of diamidoamines (Bajpai \& Tyagi, 2008)

to $10 \%$ of amidoamines and up to $1 \%$ of alkyl triamines as the main components. The substance is obtained by cyclisation of diamidoamines at elevated temperatures producing imidazolines $\mathrm{D}_{2} \mathrm{R}$ and water (Figure 4).

The modifiers used in their production are high molecular weight fatty acids. Their chemical reactivity results not only from the fivemember ring containing two nitrogen atoms but also from the function groups: $\mathrm{NH}_{2}$ (imidazoline Type 1) and $\mathrm{NH}-\mathrm{CO}$ (imidazoline Type 2). From the two places exhibiting chemical reactivity in imidazoline the higher potential has the five-member ring containing two nitrogen atoms that are highly reactive to bond with their neighbours by losing an electron and thus becoming a positively charged (cationic) compound with a semi-polar bond.

Lard imidazolines are in liquid form and are used as textile softeners selected fatty compounds (their compositions) are presented in Table 1.

The C18 chain contains one double bond in the cis configuration. Its presence considerably decreases the melting point (at the room temperature these substances are in liquid form).

Table 1. Composition of alkyl groups in fatty acids*

\begin{tabular}{lcccc}
\hline \multirow{2}{*}{ Raw material } & \multicolumn{4}{c}{ Chain length } \\
\cline { 2 - 5 } & $\mathbf{C 1 4}$ & $\mathbf{C 1 6}$ & $\mathbf{C 1 8}$ & $\mathbf{C 1 8}^{\prime}$ \\
\hline Olein & - & 5 & 20 & 75 \\
Lard & 5 & 30 & 20 & 45 \\
Hydrated lard & 5 & 30 & 65 & - \\
Stearic & - & 5 & 95 & - \\
\hline
\end{tabular}

Note: by Gawel, Czechowski, \& Kosno (2016). 


\subsection{Research on bitumen with the addition of imidazoline - testing methods}

The influence of lard imidazoline was determined in the tests carried out on two types of bitumen, namely: straight-run bitumen (Type 1) and oxidised bitumen (Type 2). The type of bitumen used in this research was $20 / 30$ pen-grade bitumen with the characteristics approximating those of the bitumen contained in the RAP material. The experimental determinations included:

- penetration at $5^{\circ} \mathrm{C}$ and $25^{\circ} \mathrm{C}$ respectively (PN-EN 1426:2015 Bitumen and Bituminous Binders - Determination of Needle Penetration);

- Ring and Ball (R\&B) softening point (PN-EN 1427:2015 Bitumen and Bituminous Binders - Determination of the Softening Point Ring and Ball Method);

- tensile properties by force ductility method at $10^{\circ} \mathrm{C}$ (the maximum tensile force according to PN-EN 13589:2018 Bitumen and Bituminous Binders - Determination of the Tensile Strength of Modified Bitumens, the Ductile Method, conventional energy in elastic and plastic regions according to PN-EN 13589:2018 and PN-EN ISO 13703:2004 Petroleum and Natural Gas Industries - Design and Installation of Piping Systems on Offshore Production Platforms);

- complex shear modulus $G^{*}$ and phase angle $\delta$ at $52^{\circ} \mathrm{C}$ in Dynamic Shear Rheometer (DSR) (PN-EN 14770:2012 Bitumen and Bituminous Binders - Determination of Complex Shear Modulus and Phase Angle - Dynamic Shear Rheometer (DSR)).

All properties were determined under European Standards. The bitumen test samples (approximately $5 \mathrm{dm}^{3}$ ) were heated up to $160^{\circ} \mathrm{C}$ in an airtight container (10 $\mathrm{dm}^{3}$ volume). The container was held in an oil bath that guaranteed even heating of the asphalt. At reaching the assumed temperature, the modifier was added to the bitumen $(1 \%-5 \%)$.

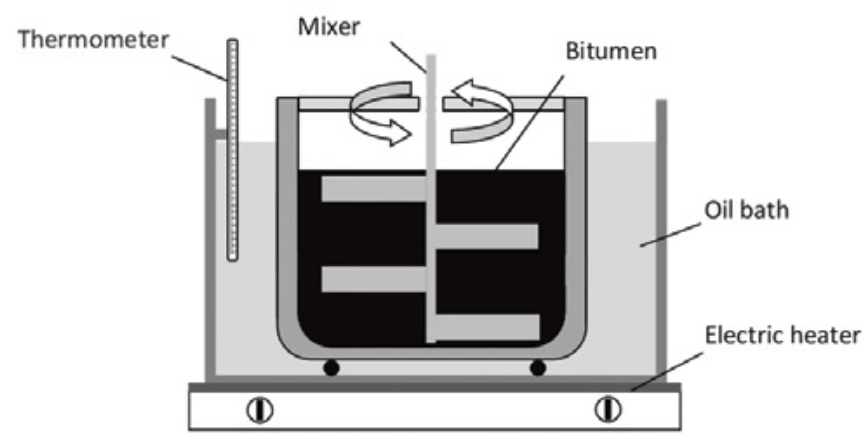

Figure 5. Diagram of the oil bath equipment for modifying the bitumen 
The mix was then mixed adequately for $20 \mathrm{~min}$ at $240 \mathrm{rpm}$ (Figure 5). While the mixing speed was reduced to $120 \mathrm{rpm}$ for the next $10 \mathrm{~min}$, the heating was then turned off. The finished product was then tested.
Potential of Using Imidazoline

in Recycled Asphalt Pavement

\subsection{Results and analysis of the tests on bitumen with imidazoline}

Figures 6-10 illustrate the test results. The tests were performed for asphalts 20/30 (Type 1 - straight-run asphalt, Type 2 - oxidised asphalt) with different content of the imidazoline $(1 \%-5 \%$ at $1 \%$ increment).

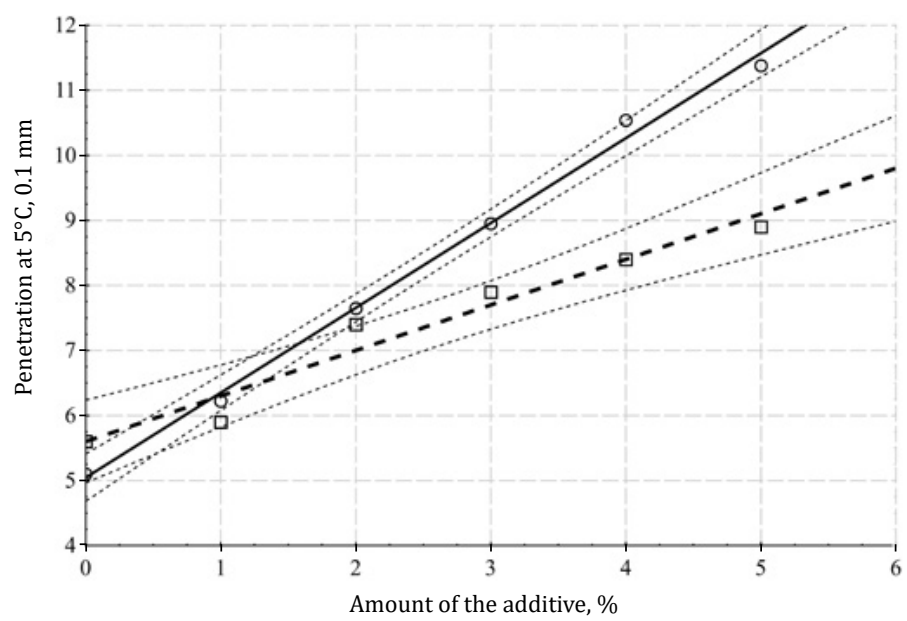

Figure $6 a$. Penetration at $5^{\circ} \mathrm{C}$

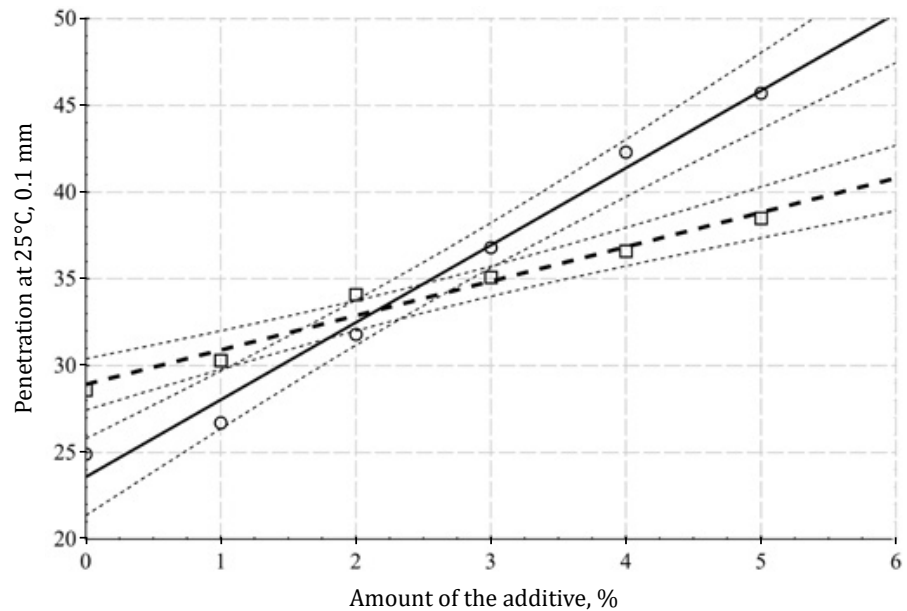

Figure $6 \mathrm{~b}$. Penetration at $25^{\circ} \mathrm{C}$
Q Bitumen 20/30 Type 1:

$y=5.0452+1.3046 x ; r^{2}=0.9956$

ㄴ. Bitumen 20/30 Type 2: $y=5.6000+0.7000 x ; r^{2}=0.9554$

Q Bitumen 20/30 Type 1:

$y=23.5714+4.4514 x ; r^{2}=0.9862$

ᄂ Bitumen 20/30 Type 2:

$y=28.9095+1.9829 x ; r^{2}=0.9695$

Note: PN-EN 1426:2015 Bitumen and Bituminous Binders Determination of Needle Penetration 
Q Bitumen 20/30 Type 1:

$y=66.0000-1.8800 x ; r^{2}=0.9622$

\. Bitumen 20/30 Type 2:

$y=62.0571-0.6229 x ; r^{2}=0.9811$

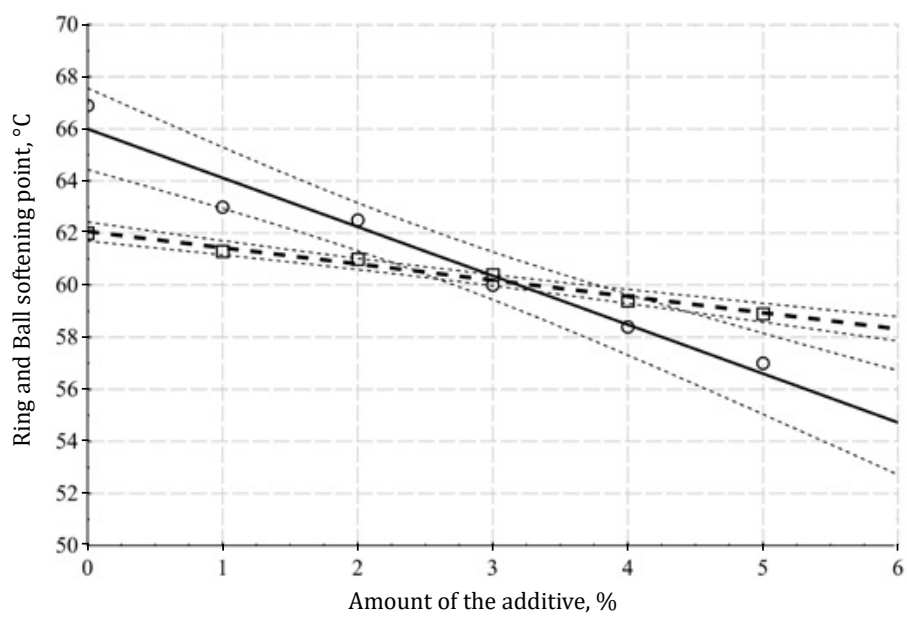

Note: PN-EN 1427:2015 Bitumen and Bituminous Binders - Determination of the Softening Point - Ring and Ball Method

Figure 7. Ring and Ball softening point

Q Bitumen 20/30 Type 1:

$y=3.2518-0.2589 x ; r^{2}=0.9844$

ㄴ. Bitumen 20/30 Type 2:

$y=2.3856-0.1013 x ; r^{2}=0.9847$

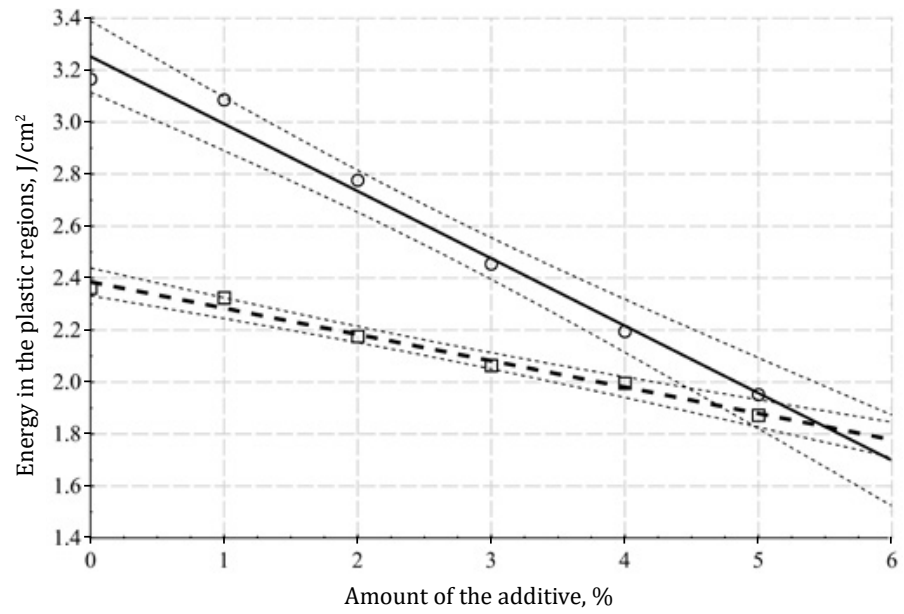

Note: PN-EN 13589:2018 Bitumen and Bituminous Binders - Determination of the Tensile Strength of Modified Bitumens, the Ductile Method; PN-EN ISO 13703:2004 Petroleum and Natural Gas Industries Design and Installation of Piping Systems on Offshore Production Platforms

Figure 8a. Conventional energy in the plastic regions in the force ductility method 


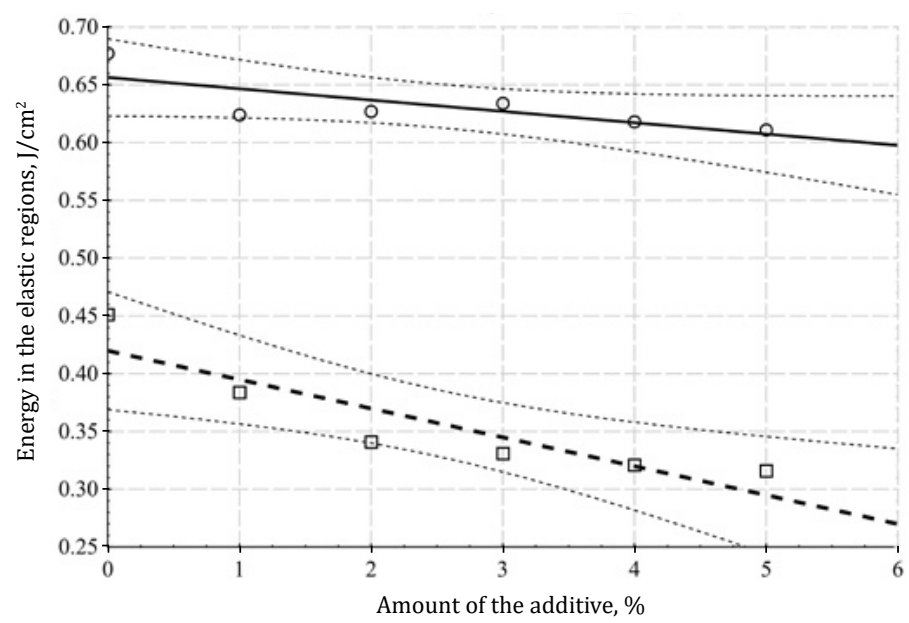

Potential of Using Imidazoline in Recycled Asphalt Pavement

Figure 8b. Conventional energy in the elastic regions in the force ductility method

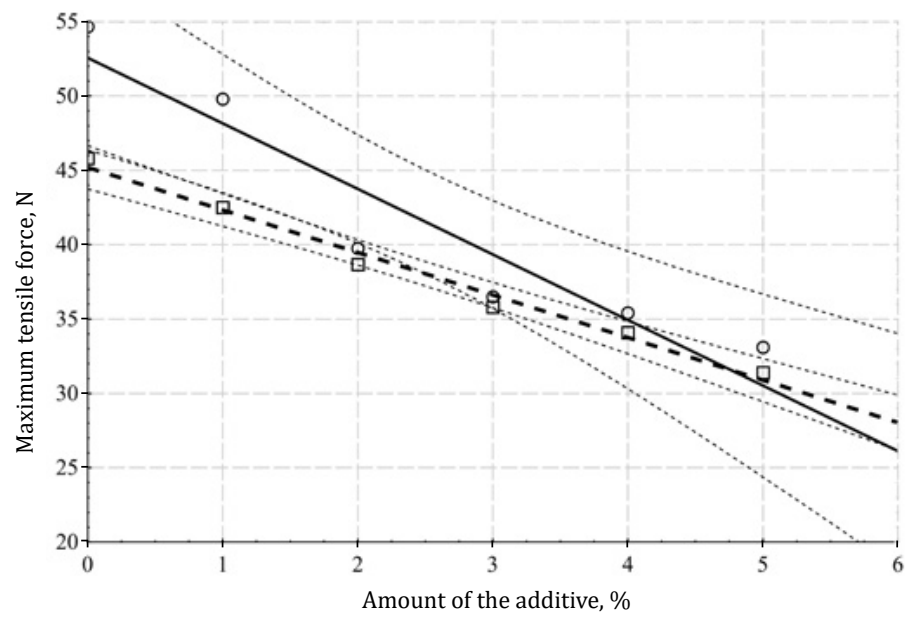

Q Bitumen 20/30 Type 1 : $y=0.6563-0.0098 x ; r^{2}=0.6024$

\. Bitumen 20/30 Type 2: $y=0.4199-0.0250 x ; r^{2}=0.8089$

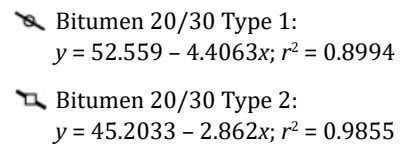

Q Bitumen $20 / 30$ Type 1

Bitumen 20/30 Type 2: $y=45.2033-2.862 x ; r^{2}=0.9855$

Figure 9. The maximum tensile force in the force ductility method

Moreover, the value of the PI was determined based on the obtained penetration values (at two temperatures) and the R\&B softening point (Figure 11).

The results show that the addition of lard imidazoline significantly changes the parameters of both the tested 20/30 bitumens, with more considerable differences observed in the case of straight-run 
Q Bitumen 20/30 Type 1: $y=44.5877-5.5258 x ; r^{2}=0.8972$

\. Bitumen 20/30 Type 2: $y=37.7783-4.4184 x ; r^{2}=0.9277$

Bitumen 20/30 Type 1 : $y=66.8048+0.9714 x ; r^{2}=0.9846$

\. Bitumen 20/30 Type 2: $y=68.4095-0.9629 x ; r^{2}=0.9780$
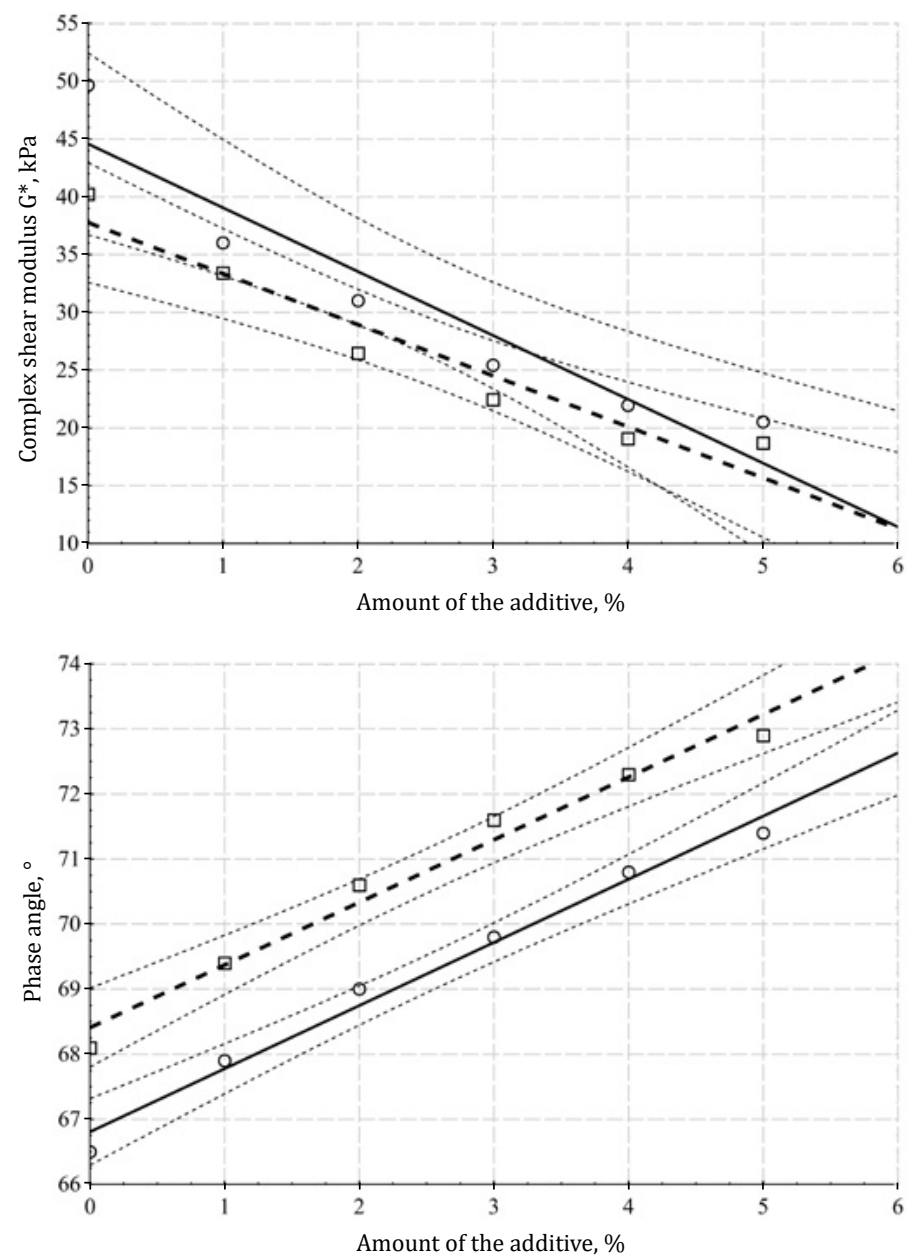

Note: PN-EN 14770:2012 Bitumen and Bituminous Binders - Determination of Complex Shear Modulus and Phase Angle - Dynamic Shear Rheometer (DSR)

Figure 10. Complex shear modulus and phase angle obtained in Dynamic Shear Rheometer

bitumen. The parameter that has changed the most is penetration at $5^{\circ} \mathrm{C}$ (Figure 6) - for both the tested 20/30 bitumens (at $5 \%$ addition the value for oxidised asphalt was 59\% while for straight-run asphalt was $123 \%$ ), followed by penetration at $25^{\circ} \mathrm{C}$ that increased by between $35 \%$ (Type 2) and $84 \%$ (Type 1). The Ring and Ball softening point (Figure 7) and $\delta$ (Figure 10) have changed the least. Addition of $5 \%$ of imidazoline decreases the softening point of both bitumens by $5 \%-15 \%$ (concerning 


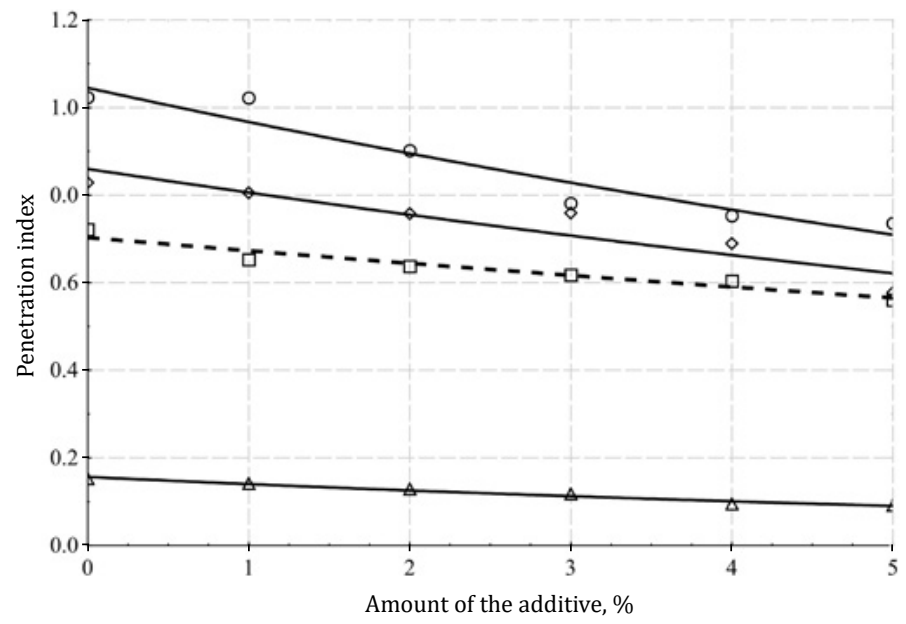

\. Bitumen $20 / 30$ Type 1 (Pen/Pen)

Bitumen 20/30 Type 2 (Pen/Pen)

ㄴ. Bitumen 20/30 Type 1 (Pen/R\&B)

$\chi$ Bitumen 20/30 Type 2 (Pen/R\&B)

Figure 11. Penetration index based on two methods

the initial value determined for virgin bitumen). The oxidised bitumen exhibited small changes in the softening point (5\%) than the straight-run asphalt (15\%). The obtained values for conventional energy in elastic and plastic regions (Figure 8) show that the addition of the imidazoline is mainly responsible for the decrease in the conventional energy in the latter. A more significant decrease (38.3\%) of the conventional energy was observed in straight-run asphalt (Type 1). The oxidised asphalt (Type 2) exhibited a decrease of conventional energy by $20.7 \%$. The total amount of the conventional energy (sum of the energy in plastic and elastic regions) was higher for the Type 1 asphalt that suggests a higher cohesion of the bitumen. As a result the bitumen exhibit higher resistance to rutting.

Higher conventional energy values in Type 1 asphalt were proven by higher values obtained in the force ductility method (Figure 9). Again, higher values (39.5\%) were recorded for the straight-run asphalt (Type 1). The oxidised asphalt exhibited a change by approximately $31.5 \%$ ).

The results obtained in both tests (conventional energy determination and maximum force) were also reflected in the determination of $G^{*}$ and $\delta$ (Figure 10). The straight-run asphalt (Type 1) exhibited higher values of $G^{*}$ and lower $\delta$. The mean difference in $G^{*}$ for both asphalts was approximately $5 \mathrm{kPa}$. The difference in $\delta$ was $1^{\circ}$. The addition of the imidazoline decreases the values of $G^{*}$. In the straight-run asphalt (Type 1 ) at $5 \%$ of additive, the $G^{*}$ decreased by $58.6 \%$ while for Type 2 oxidised asphalt the decreased reached $53.5 \%$. The phase angle $\delta$ (Figure 9) increased by circa about $7 \%$ in the case of both studied bitumen. ential of Using

in Recycled Asphalt Pavement 
Bitumen 20/30 Type 1

¿ Bitumen 20/30 Type $1+\mathrm{IM}$

จ. Bitumen $20 / 30$ Type 2

A. Bitumen 20/30 Type 2+IM

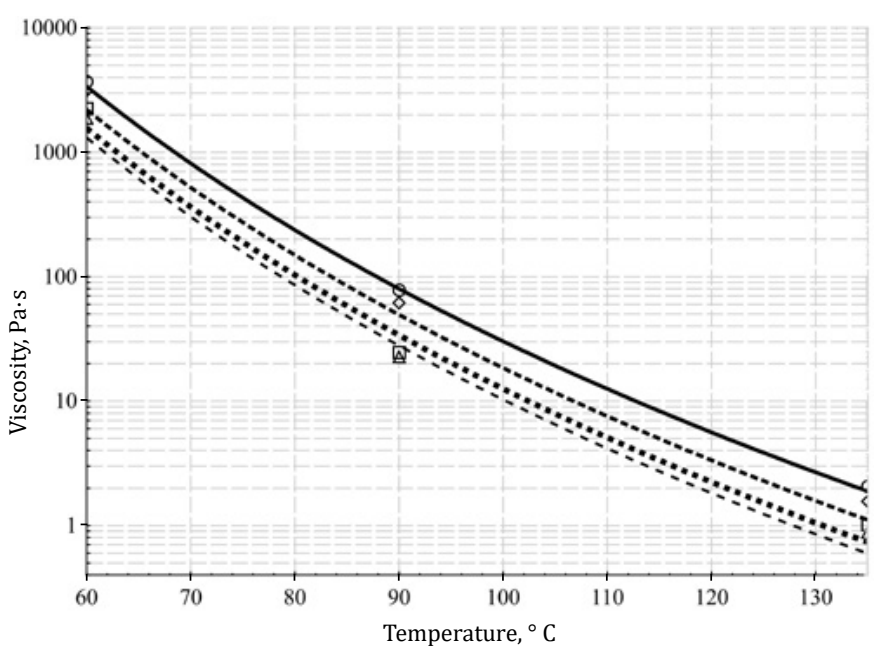

Figure 12. The influence of $3 \%$ addition of lard imidazoline on the viscosity of $20 / 30$ bitumen

The rheological properties have changed slightly because of the modification of the two bitumens with lard imidazoline. The values of (Figure 11), determined with two methods (Pen/Pen and Pen/R\&B) decrease as more additive is added, yet both bitumens retain the sol-gel behaviour. Slightly more significant changes were observed in the case of straight-run bitumens, and this is an indication of their slightly higher temperature sensitivity.

Based on the changes occurring in bitumens, it is expected that the addition of lard imidazoline will reduce the viscosity of the mixture, lowering. As a result, the temperature of the bitumen-aggregate mixture during production and placement. This test has been confirmed by the experimentally determined viscosities of 20/30 bitumens (from both manufacturers) modified by addition of $3 \%$ of imidazoline. The test results are illustrated in Figure 12.

As seen, the addition of lard imidazoline decreases the viscosity of bitumen and enables reduction of the temperatures of the production processes (coating, compaction) by approximate $10^{\circ} \mathrm{C}$.

\subsection{Properties of the recycled asphalt pavement material used in the research}

For more effective and faster mixing of imidazoline with RAP material (specifically with the aged bitumen contained in it), a bitumen and imidazoline concentrate was used, containing $80 \%$ of imidazoline 
Table 2. Experimentally determined content and parameters of binder

\begin{tabular}{|c|c|c|}
\hline Test & Method & Result \\
\hline Binder content, \% & $\begin{array}{l}\text { PN-EN 12697-1:2012 } \\
\text { Bituminous Mixtures - } \\
\text { Test Methods for Hot Mix Asphalt - } \\
\text { Part 1: Soluble Binder Content } \\
\text { PN-EN 12697-3:2013 } \\
\text { Bituminous Mixtures - } \\
\text { Test Methods for Hot Mix Asphalt - Part 3: } \\
\text { Bitumen Recovery: Rotary Evaporator }\end{array}$ & $\begin{array}{c}3.9500 \pm \\
0.12\end{array}$ \\
\hline $\begin{array}{l}\text { Penetration } \\
\text { at } 25^{\circ} \mathrm{C}, \times 0.1 \mathrm{~mm}\end{array}$ & $\begin{array}{l}\text { PN-EN 1426:2015 } \\
\text { Bitumen and Bituminous Binders - } \\
\text { Determination of Needle Penetration }\end{array}$ & $\begin{array}{c}19.200 \pm \\
1.80\end{array}$ \\
\hline $\begin{array}{l}\text { Ring and Ball } \\
\text { softening point, }{ }^{\circ} \mathrm{C}\end{array}$ & $\begin{array}{l}\text { PN-EN 1427:2015 } \\
\text { Bitumen and Bituminous Binders - } \\
\text { Determination of the Softening Point - } \\
\text { Ring and Ball Method }\end{array}$ & $\begin{array}{c}72.600 \pm \\
3.67\end{array}$ \\
\hline $\begin{array}{c}\text { Maximum density } \\
\text { of } \mathrm{HMA}_{1} \mathrm{~g} / \mathrm{cm}^{3}\end{array}$ & $\begin{array}{l}\text { PN-EN 12697-5:2010 AC } 2012 \\
\text { Bituminous Mixtures - Test Methods for Hot } \\
\text { Mix Asphalt - Part 5: Determination } \\
\text { of the Maximum Density, method A in water }\end{array}$ & $\begin{array}{l}2.680 \pm \\
0.09\end{array}$ \\
\hline Bulk density of Hot & $P N-E N$ 12697-6:2012 & \\
\hline Mix Asphalt, $\mathrm{g} / \mathrm{cm}^{3}$ & $\begin{array}{l}\text { Bituminous Mixtures - Test Methods for Hot } \\
\text { Mix Asphalt - Part 6: Determination of Bulk } \\
\text { Density of Bituminous Specimens, method B }\end{array}$ & $\begin{array}{c}2.479 \pm \\
0.05\end{array}$ \\
\hline Air void content, \% & $\begin{array}{l}\text { PN-EN 12697-8:2005 } \\
\text { Bituminous Mixtures - Test Methods for Hot } \\
\text { Mix Asphalt - Part 8: Determination of Void } \\
\text { Characteristics of Bituminous Specimens }\end{array}$ & $\begin{array}{l}7.500 \pm \\
0.40\end{array}$ \\
\hline
\end{tabular}

Potential of Using Imidazoline in Recycled Asphalt Pavement

and $20 \%$ of $50 / 70$ pen-grade bitumen. The concentrate was heated up to approximate $80^{\circ} \mathrm{C}-100^{\circ} \mathrm{C}$ and added in liquid form.

The RAP material was obtained from the bituminous base course layer. According to the information obtained from the road administrator, the mixture was placed in the early 1980s. A macroscopic and organoleptic evaluation was sufficient to observe the effects of ageing, including high brittleness at ambient temperature. The results of the tests performed to determine the mixture type (grading), air voids content, and the content and classification parameters of the bituminous binder are presented in Table 2 and Figure 13. 


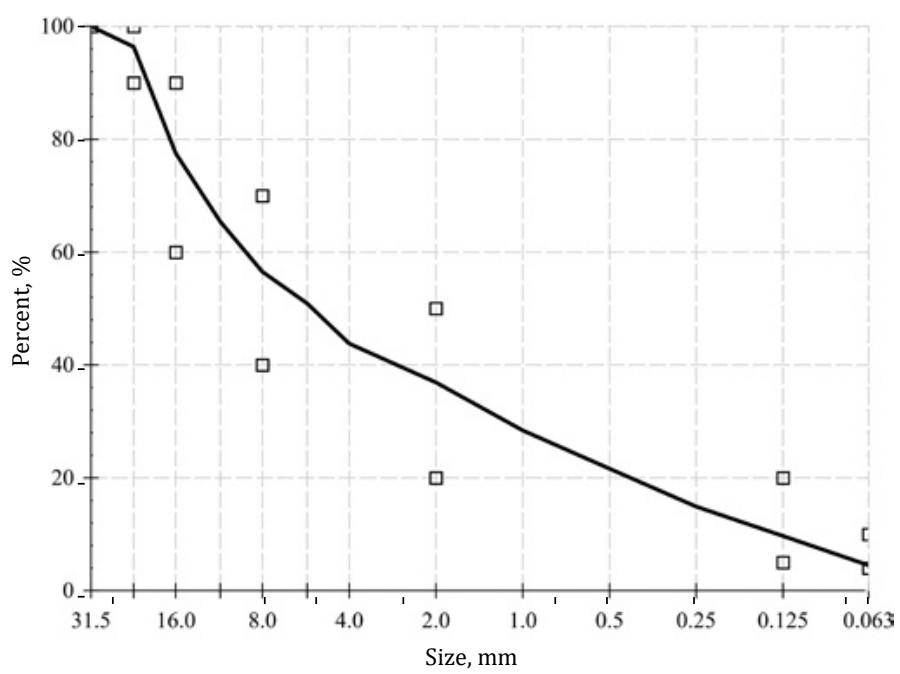

Figure 13. Grading of the mineral mixture extracted from the recycled asphalt pavement material

Table 3. Results of the experimental determination of the bituminous concrete properties

\begin{tabular}{|c|c|c|}
\hline \multicolumn{2}{|l|}{ Test } & \multirow{2}{*}{$\frac{\text { Result }}{0.04}$} \\
\hline $\begin{array}{l}\text { Rutting resistance, } P N-E N \text { 12697-22:2008 + A1 } \\
2008 \text { Bituminous Mixtures - Test Methods }\end{array}$ & $\begin{array}{l}\text { WTS } \\
\mathrm{mm} / 10^{3} \text { cycles }\end{array}$ & \\
\hline $\begin{array}{l}\text { for Hot Mix Asphalt - Part 22: Wheel Tracking, } \\
60^{\circ} \mathrm{C}, 10000 \text { cycles }\end{array}$ & $P R D_{A I R}, \%$ & 3.37 \\
\hline $\begin{array}{l}\text { Stiffness, PN-EN 12697-26:2018-08 Bituminous } \\
\text { Methods for Hot Mix Asphalt - Part 26: Stiffnes } \\
10^{\circ} \mathrm{C}, 10 \mathrm{~Hz}, \mathrm{MPa}\end{array}$ & $\begin{array}{l}\text { Ires - Test } \\
\text { nexe B) 4PB-PR, }\end{array}$ & 19457 \\
\hline $\begin{array}{l}\text { Resistance to fatigue, } P N-E N \text { 12697-24:2018 Asf } \\
\text { Methods - Part 24: Resistance to Fatigue (anne } \\
10 \mathrm{~Hz}, \varepsilon=115 \mu \varepsilon, 10^{6} \text { cycles }\end{array}$ & $\begin{array}{l}\text { Mixtures - Test } \\
\text { 4PB-PR, } 10^{\circ} \mathrm{C}\end{array}$ & 0.68 \\
\hline
\end{tabular}

Based on the sieve analysis, the aggregate mixture classifies as a minus $25 \mathrm{~mm}$ relatively densely graded $(4.5 \%-8 \%$ according to the Polish standard PN-S-96022:1974 Drogi Samochodowe i Lotniskowe Nawierzchnie $z$ Betonu Asfaltowego) or densely graded mixture designated for bituminous base courses. With a relatively low content of the filler fraction, with the air as mentioned above voids content, the mixture has to be placed closer to the relatively densely graded 
mixture type. The binder was most probably D35 bitumen (classification according to PN-65/C-96170:1965 Przetwory Naftowe - Asfalty Drogowe).

Additional tests were carried out to assess the strength properties of the bituminous mixture, namely resistance to deformation, stiffness and fatigue performance (Table 3). The tests were performed European Standards (test methods listed in Table 3).

\subsection{Properties of the bituminous mixture after modification}

The mixture was subjected to tests to assess the influence of rejuvenator on its physical and strength properties. The test pieces were made of RAP without additives and with an addition of the rejuvenator concentrate (a mix of asphalt and lard imidazoline of $0.2 \%-0.6 \%$ (at $0.2 \%$ increments) concerning the RAP weight.

In the initial step of the experiment, the time optimum mixing time was determined to obtain a homogenous bituminous mixture containing lard imidazoline. The determination was based on the spread of bulk densities of Marshal specimens moulded at $145^{\circ} \mathrm{C}$ after different mixing times (from $30 \mathrm{~s}$ to $5 \mathrm{~min}$ ). The process of Marshall compaction and determination of bulk density were performed under European Standards (PN-EN 12697-30:2019-01 for compaction, PN-EN 126976:2012 Bituminous Mixtures - Test Methods for Hot Mix Asphalt - Part 6: Determination of Bulk Density of Bituminous Specimens for bulk density). The determination was carried out for the mixture containing $0.6 \%$ of imidazoline and bitumen concentrate. The process of mixing the RAP material pre-heated to $160 \pm 5^{\circ} \mathrm{C}$ was carried out in a heated mixer with

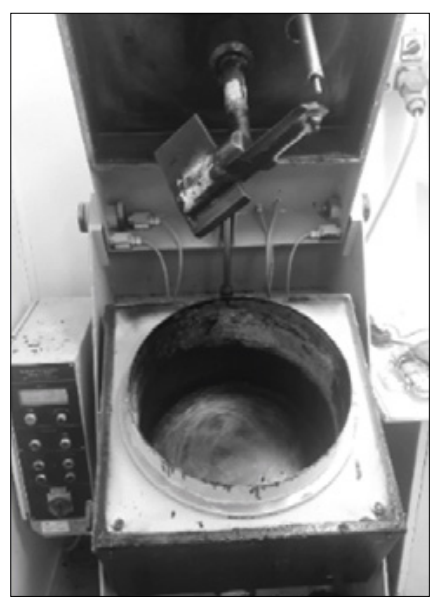

Figure 14. Mixer equipped with heating and temperature control systems
Potential of Using Imidazoline in Recycled Asphalt Pavement 
fully controlled temperature (Figure 14). The test results are presented in Figure 15. On this basis, two minute mixing time at $155^{\circ} \mathrm{C}-165^{\circ} \mathrm{C}$ was adopted in the subsequent part of the experiment. This period ensured stable bulk density (both, in terms of the average value and spread of results). This shortening of the mixing time enabled the mitigation of production ageing of bitumen.

The main part of the experiment consisted of the determination of the:

- maximum density (PN-EN 12697-5:2010 AC 2012 Bituminous Mixtures - Test Methods for Hot Mix Asphalt - Part 5: Determination of the Maximum Density);

- bulk density (PN-EN 12697-6:2012 Bituminous Mixtures - Test Methods for Hot Mix Asphalt - Part 6: Determination of Bulk Density of Bituminous Specimens);

- resistance to permanent deformation (PN-EN 12697-22+A1:2008 Bituminous Mixtures - Test Methods for Hot Mix Asphalt - Part 22: Wheel Tracking);

- stiffness 4 PB-PR (PN-EN 12697-26:2018 Bituminous Mixtures Test Methods for Hot Mix Asphalt - Part 26: Stiffness (annexe B));

- fatigue performance 4PB-PR (PN-EN 12697-24:2018 Asphalt Mixtures - Test Methods - Part 24: Resistance to Fatigue (annexe D));

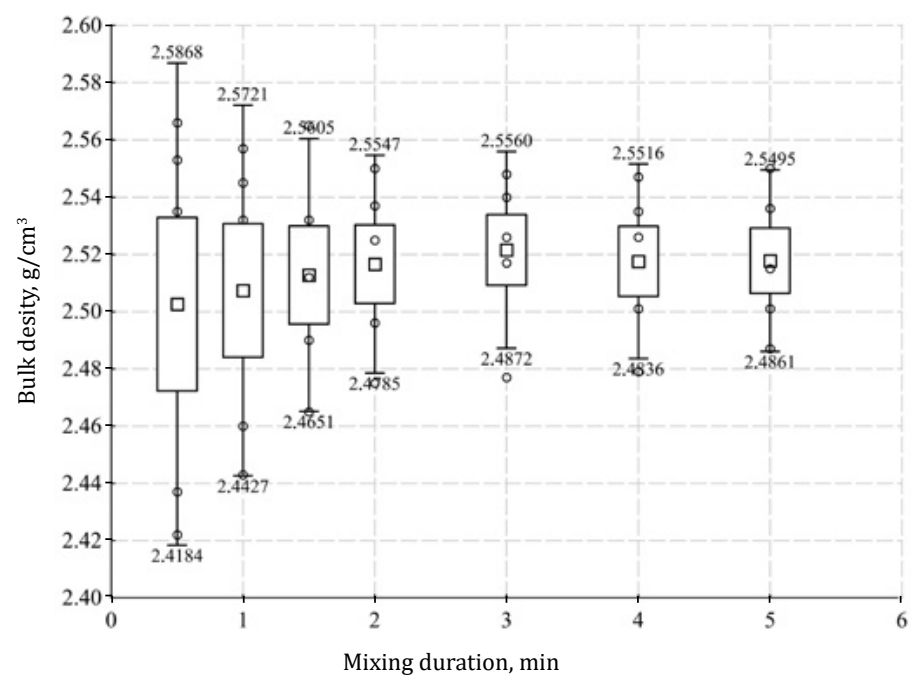

Figure 15. The effect of the mixing duration on the bulk density of the mixture containing $0.6 \%$ 
Table 4. Experimentally determined parameters of the tested bituminous mixture*

\begin{tabular}{|c|c|c|c|c|}
\hline \multirow{2}{*}{ Parameter } & \multicolumn{4}{|c|}{ Amount of additives, $\%$} \\
\hline & 0 & 0.2 & 0.4 & 0.6 \\
\hline $\begin{array}{l}\text { Binder content, } \% \\
\text { - weight ratio, } \mathrm{m} / \mathrm{m} \\
\text { - volume ration, } \mathrm{vol} / \mathrm{vol}\end{array}$ & $\begin{array}{l}3.95 \\
9.60\end{array}$ & $\begin{array}{r}4.15 \\
10.19\end{array}$ & $\begin{array}{r}4.35 \\
10.73\end{array}$ & $\begin{array}{r}4.55 \\
11.25\end{array}$ \\
\hline Maximum density of $\mathrm{HMA}, \mathrm{g} / \mathrm{cm}^{3}$ & 2.680 & 2.671 & 2.662 & 2.653 \\
\hline Bulk density of HMA, $\mathrm{g} / \mathrm{cm}^{3}$ & 2.479 & 2.492 & 2.507 & 2.517 \\
\hline Air voids content the mixture, $\%$ & 7.49 & 6.69 & 5.81 & 5.14 \\
\hline $\begin{array}{l}\text { Rutting resistance, method } \mathrm{B} \text { in } \\
\text { air, } 60^{\circ} \mathrm{C}, 10000 \text { cycles } \\
\text { - } W T S_{A I R} \mathrm{~mm} / 10 \text { cycles } \\
\text { - } P R D_{A I R} \%\end{array}$ & $\begin{array}{l}0.04 \\
3.40\end{array}$ & $\begin{array}{l}0.16 \\
6.90\end{array}$ & $\begin{array}{r}0.32 \\
11.80\end{array}$ & $\begin{array}{r}0.44 \\
20.50\end{array}$ \\
\hline $\begin{array}{l}\text { Resistance to fatigue, } 4 \text { PB-PR, } \\
10^{\circ} \mathrm{C}, 10 \mathrm{~Hz}, \varepsilon=115 \mu \varepsilon\end{array}$ & 67705 & 496321 & 794043 & 1382106 \\
\hline
\end{tabular}

- resistance to the action of water and freezing temperatures (PNEN 12697-12:2018 Bituminous Mixtures - Test Methods - Part 12: Determination of the Water Sensitivity of Bituminous Specimens).

The tests were performed under European Standards. The test results are presented in Table 4 and Figures 16-19.

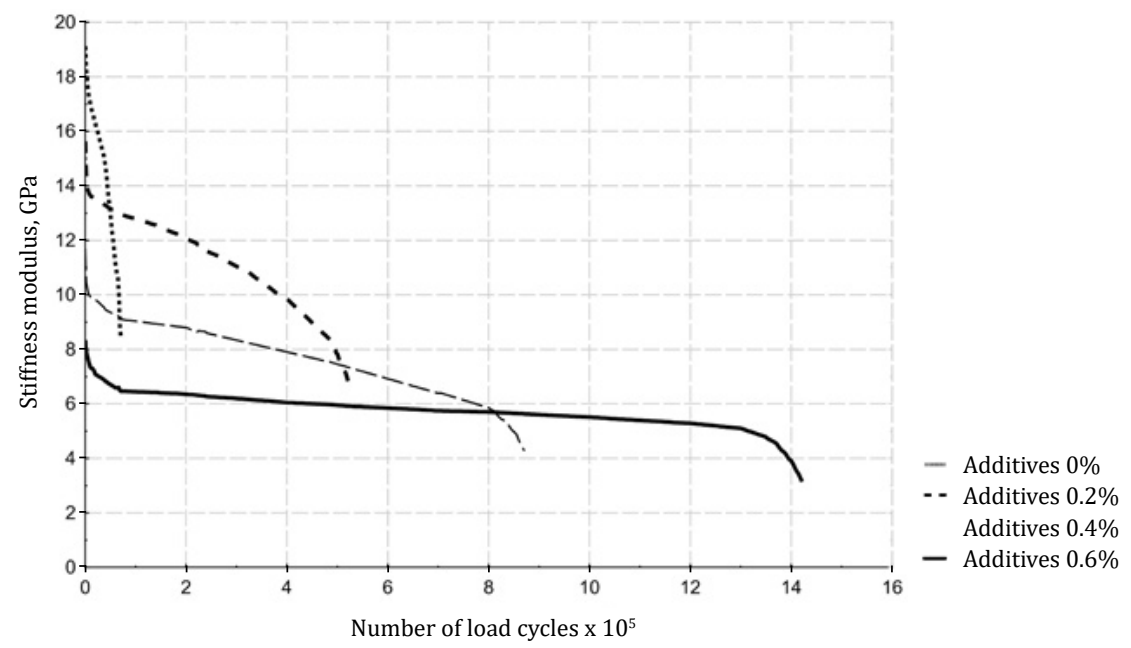

Note: mean values.

Figure 16. The effect of rejuvenator on the fatigue performance
Potential of Using Imidazoline in Recycled Asphalt Pavement 


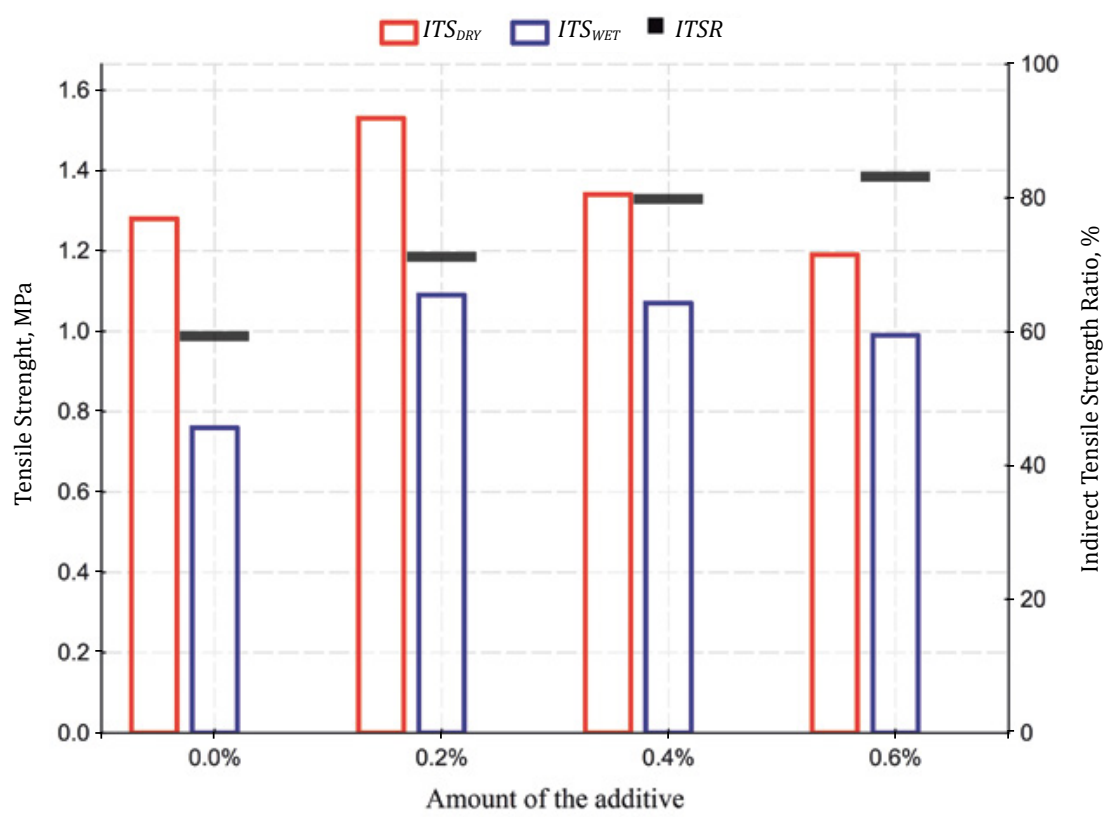

Figure 17. The effect of rejuvenator on the Indirect Tensile Strength and sensitivity to water determined

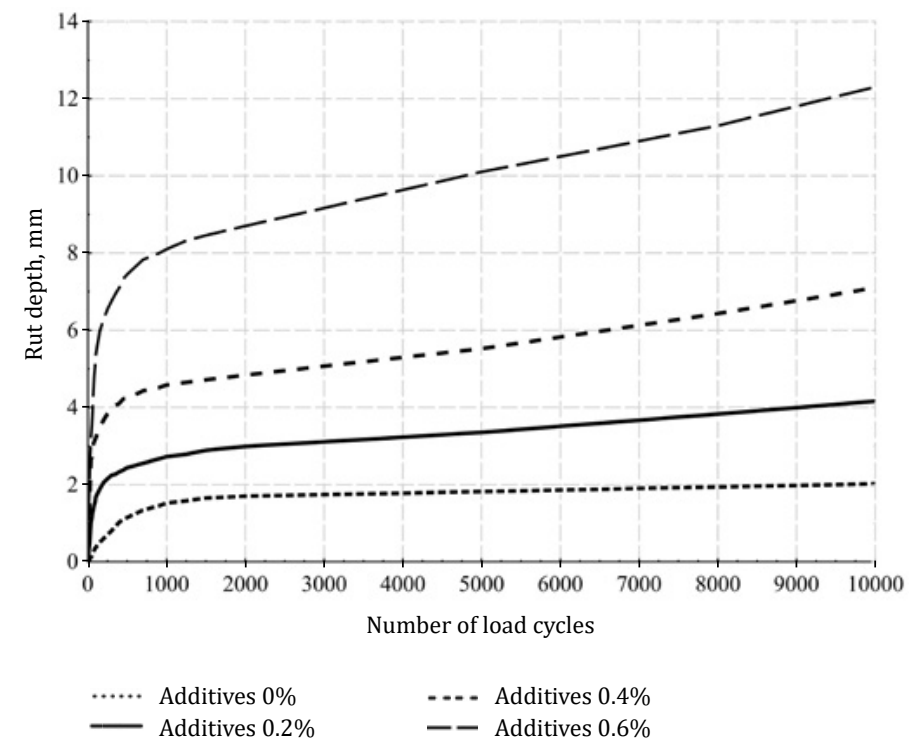

Figure 18. The effect of rejuvenator on the resistance to visco-plastic deformation 


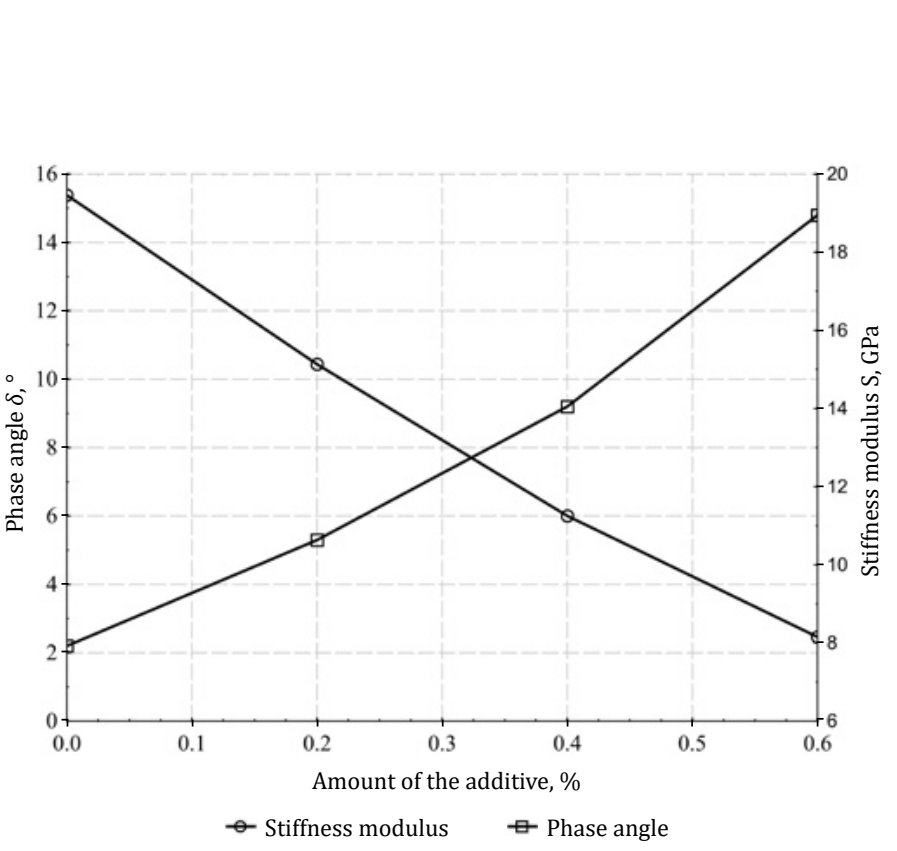

Figure 19. The effect of rejuvenator on the stiffness modulus and phase angle

Addition of rejuvenator improves most properties of the test pieces moulded from RAP material. Among the physical properties, the density increased from $2.479 \mathrm{~g} / \mathrm{cm}^{3}$ (virgin mixture) do $2.517 \mathrm{~g} / \mathrm{cm}^{3}$ (mixture containing $0.6 \%$ of rejuvenator), reducing the air voids content by over $30 \%$ (from $7.5 \%$ in virgin mixture to $5.1 \%$ in mixture containing $0.6 \%$ of rejuvenator).

The larger binder content (and thus a lower content of air voids) and the changes in hardness (softening) have noticeably increased the fatigue performance of the specimens, as determined in the 4 PB-PR test. For the virgin mixture specimens, the initial stiffness modulus decreased by $50 \%$ after circa $0.07 \cdot 10^{6}$ cycles. For the specimens containing $0.6 \%$ of imidazoline and bitumen concentrate the number of cycles increased to $1.38 \cdot 10^{6}$ that ensures the desired end-use performance of the mixture.

Among other performance characteristics, improved resistance to the action of water and frost was noted based on the Indirect Tensile Strength Ratio (ITSR) value of $83 \%$ obtained for the mixture containing $0.6 \%$ of rejuvenator. This test is attributed primarily to a higher Indirect Tensile Strength (ITS) of the specimens subjected to the tensile test at freezing temperatures after conditioning in water $\left(I T S_{\text {wet }}\right)$. The factors responsible for this improvement include a more significant content of bitumen, higher bulk density of specimens, improved compatibility and better adhesion of binder to the mineral aggregate (the effect of imidazolines on the surface tension). 
The change of parameters of the bituminous mixture specimens as a result of rejuvenator addition is observed on the basis of the stiffness modulus $S$ (it decreased from $19.5 \cdot 10^{3} \mathrm{MPa}$ to $8.1 \cdot 10^{3} \mathrm{MPa}$ ) and it is yet more evident when it is compared to the values of $\delta$ it increased from $2.2^{\circ}$ to $14.8^{\circ}$ ). The experimental results also show a more plastic behaviour of the mixture.

The more plastic behaviour of the mixtures containing imidazoline and bitumen rejuvenator is indicated by a higher susceptibility to viscoplastic deformations, as determined in the wheel-tracking test. The results show that the resistance to permanent deformation decreases considerably with the increase in the amount of the rejuvenator added to the mixture, both for $P R D_{A I R}$ (increase from $3.4 \%$ to $20.5 \%$ ) and for $W T S_{\text {AIR }}$ (increase from $0.04 \mathrm{~mm} / 103$ to $0.44 \mathrm{~mm} / 10^{3}$ cycles).

\section{Conclusions}

1. The results of experimental research confirm the suitability of imidazoline and bitumen concentrate for rejuvenating recycled asphalt pavement material in the hot recycling process.

2. The improvement was particularly evident in the 4 PB-PR test, that showed an over 7 -fold increase of the fatigue resistance after addition of only $0.2 \%$ of rejuvenator.

3. A more plastic behaviour was observed, indicated by the smaller value of the stiffness modulus and an increase in the value of the phase angle.

4. Lard imidazoline, owing to its surface activity, improves adhesion of bitumen to aggregate and resistance of the mixture to the action of water and exposure to freezing temperatures.

5. Addition of the imidazoline-bitumen concentrate to the bituminous mixtures considerably increases their susceptibility to permanent deformation, this calling for further research, covering, without limitation, the introduction of an additional stabilising agent to limit the visco-plastic deformations at elevated temperatures.

\section{REFERENCES}

Bajpai, D., \& Tyagi, V. K. (2008). Synthesis and characterization of imidazolinium surfactants derived from tallow fatty acids and diethylenetriamine. European Journal of Lipid Science and Technology, 110(10), 935-940.

https://doi.org/10.1002/ejlt.200800046 
Čygas, D., Mučinis, D., Sivilevičius, H., \& Abukauskas, N. (2011). Dependence of the recycled asphalt mixture physical and mechanical properties on the grade and amount of rejuvenating bitumen. The Baltic Journal of Road and Bridge Engineering, 6(2), 124-134. https://doi.org/10.3846/bjrbe.2011.17

Feng, Z. G., Yu, J. Y., Zhang, H. L., Kuang, D. L., \& Xue, L. H. (2013). Effect of ultraviolet aging on rheology, chemistry and morphology of ultraviolet absorber modified bitumen. Materials and Structures, 46(7), 1123-1132. https://doi.org/10.1617/s11527-012-9958-3

Gawel, I., Czechowski, F., \& Kosno, J. (2016). An environmental friendly anti-ageing additive to bitumen. Construction and Building Materials, 110, 42-47. https://doi.org/10.1016/j.conbuildmat.2016.02.004

James, A., \& Stewart, D. (1991). The use of fatty amine derivatives to slow down the age-hardening process in bitumen. In Presented at the conference" The Chemistry of Bitumen" Rome (Vol. 671, p. 684).

Kandhal, P. S., \& Chakraborty, S. (1996). Effect of asphalt film thickness on short-and long-term aging of asphalt paving mixtures. Transportation Research Record, 1535(1), 83-90. https://doi.org/10.3141/1535-11

Kuang, D., Yu, J., Feng, Z., Li, R., Chen, H., Guan, Y., \& Zhang, Z. (2014). Performance evaluation and preventive measures for aging of different bitumens. Construction and Building Materials, 66, 209-213. https://doi.org/10.1016/j.conbuildmat.2014.04.016

Liu, M., Chaffin, J. M., Davison, R. R., Glover, C. J., \& Bullin, J. A. (1998). Changes in Corbett fraction composition during oxidation of asphalt fractions. Transportation Research Record, 1638(1), 40-46.

Lu, X., \& Isacsson, U. (2002). Effect of ageing on bitumen chemistry and rheology. Construction and Building materials, 16(1), 15-22. https://doi.org/10.1016/s0950-0618(01)00033-2

Paliukaitè, M., Vaitkus, A., \& Zofka, A. (2015) Influence of bitumen chemical composition and ageing on pavement performance. The Baltic Journal of Road and Bridge Engineering, 10(1), 97-104. https://doi.org/10.3846/bjrbe.2015.12

Piłat, J., \& Radziszewski, P. (2004) Nawierzchnie Asfaltowe. WKŁ, Warszawa, 51-53. (in Polish)

PN-65/C-96170:1965 Przetwory naftowe - Asfalty drogowe (in Polish)

PN-EN 12697-1:2012 Bituminous Mixtures - Test Methods for Hot Mix Asphalt Part 1: Soluble Binder Content

PN-EN 12697-12:2018 Bituminous Mixtures - Test Methods - Part 12: Determination of the Water Sensitivity of Bituminous Specimens

PN-EN 12697-22+A1:2008 Bituminous Mixtures - Test Methods for Hot Mix Asphalt-Part 22: Wheel Tracking

PN-EN 12697-24:2018 Bituminous Mixtures - Test Methods - Part 24: Resistance to Fatigue

PN-EN 12697-26:2018 Bituminous Mixtures - Test Methods for Hot Mix Asphalt Part 26: Stiffness

PN-EN 12697-3:2013 Bituminous Mixtures - Test Methods for Hot Mix Asphalt Part 3: Bitumen Recovery: Rotary Evaporator

PN-EN 12697-5:2010 AC 2012 Bituminous Mixtures - Test Methods for Hot Mix Asphalt - Part 5: Determination of the Maximum Density
Robert Jurczak,

Potential of Using Imidazoline in Recycled Asphalt Pavement 
PN-EN 12697-6:2012 Bituminous Mixtures - Test Methods for Hot Mix Asphalt Part 6: Determination of Bulk Density of Bituminous Specimens

PN-EN 12697-8:2005 Bituminous Mixtures - Test Methods for Hot Mix Asphalt Part 8: Determination of Void Characteristics of Bituminous Specimens

PN-EN 13589:2018 Bitumen and Bituminous Binders - Determination of the Tensile Strength of Modified Bitumens, the Ductile Method

PN-EN 1426:2015 Bitumen and Bituminous Binders - Determination of Needle Penetration

PN-EN 1427:2015 Bitumen and Bituminous Binders - Determination of the Softening Point - Ring and Ball Method

PN-EN 14770:2012 Bitumen and Bituminous Binders - Determination of Complex Shear Modulus and Phase Angle - Dynamic Shear Rheometer (DSR)

PN-EN ISO 13703:2004 Petroleum and Natural Gas Industries - Design and Installation of Piping Systems on Offshore Production Platforms

PN-S-96022:1974 Drogi Samochodowe i Lotniskowe - Nawierzchnie z Betonu Asfaltowego (in Polish)

WT-2:2014 Nawierzchnie asfaltowe na drogach krajowych (in Polish)

Wu, S., Pang, L., Mo, L., Qiu, J., Zhu, G., \& Xiao, Y. (2008). UV and thermal aging of pure bitumen-comparison between laboratory simulation and natural exposure aging. Road Materials and Pavement Design, 9(sup1), 103-113. https://doi.org/10.1080/14680629.2008.9690161

Yut, I., \& Zofka, A. (2014). Correlation between rheology and chemical composition of aged polymer-modified asphalts. Construction and Building Materials, 62, 109-117. https://doi.org/10.1016/j.conbuildmat.2014.03.043 